\title{
WATER STRUCTURING EFFECT OF METHANOL AND ETHANOL ON ION PAIRING OF SOME GUANIDIUM CONTAINIG PHARMACEUTICAL SUBSTANCES. ANALYTICAL APPLICATIONS
}

\author{
MARINELA FLOREA ${ }^{1}$, IOANA CLEMENTINA CONSTANTINESCU ${ }^{1} *$, ANGELA NEDELCU ${ }^{1}$, \\ CLAUDIA-MARIA GUȚU ${ }^{2}$, MAHER ABDULRAZZAQ LUQMAN AL-HAKEEM ${ }^{3}$, \\ LĂCRĂMIOARA POPA ${ }^{3}$
}

\author{
"Carol Davila" University of Medicine and Pharmacy, Faculty of Pharmacy, 6 Traian Vuia Street, 020956, Bucharest, Romania \\ ${ }^{I}$ Department of Analytical Chemistry \\ ${ }^{2}$ Department of Toxicology \\ ${ }^{3}$ Department of Physical and Colloidal Chemistry
}

*corresponding author: constantinescu_clementina@yahoo.com

\begin{abstract}
The influence of water structuring effect of methanol and ethanol on ion pairing of two guanidinum containing pharmaceutical compounds, namely streptomycin and arginine, was studied. Congo red was used as counterion. For this purpose, the molecular modelling, physico-chemical constants (dielectric constant, conductivity) and absorption and resonance light scattering spectrometry were used. Determinations were performed using water/alcohol binary solvent mixtures containing molar fractions of 0.05 methanol, respectively 0.03 ethanol. The results showed that, in low concentrations, methanol and ethanol favours ion pairing. For streptomycin, analytical applications were studied.
\end{abstract}

\section{Rezumat}

A fost studiată influența efectului structurant al apei determinat de metanol și etanol asupra echilibrului de asociere ionică a unor compuși farmaceutici care conțin în structură grupări guanidinice. Roșul de Congo a fost folosit drept contraion. Analiza a fost efectuată folosind modelarea moleculară, constante fizico-chimice (constantă dielectrică, conductivitate) și spectrometria de absorbție moleculară și de difuzie de rezonanță. Determinările au fost efectuate folosind amestecuri apă/alcool conținând o fracție molară de 0,05 metanol, respectiv 0,03 etanol. Rezultatele obținute au arătat că, în concentrații mici, metanolul şi etanolul favorizează formarea perechilor de ioni. Pentru streptomicină au fost studiate aplicațiile analitice.

Keywords: ion pairing, guanidinium, streptomycin, arginine, resonance light scattering

\section{Introduction}

Ion pairing, one of the fundamental interaction in chemistry and biology, describes the association of oppositely charged ions in electrolyte solutions with the formation of distinct chemical species called ion pairs [23]. Since the introduction of the concept, ion pairs are intensively studied by physical chemistry and used in pharmaceutical field $[3,5,7,12]$. Also known as ionic associations or ionic association complexes, ion pairs were defined by Bjerrum in 1926. He stated that ion pairs are formed when two oppositely charged ions approach each other to a distance smaller than the q value which equals

$$
q=\frac{8.36 \cdot 10^{6} z^{+} z^{-}}{\varepsilon_{r} T} \mathrm{pm}
$$

( $\mathrm{z}^{+}$and $\mathrm{z}^{-}$are the charge numbers of the ions, $\varepsilon_{\mathrm{r}}$ is the relative permittivity of the medium) [10]. Thus ion pairing, based on the electrostatic interactions, is dependent on the dielectric constant of the solvent, on the temperature and on the charge of the ions. According to the Bjerrum model, ion pairs were considered only in solvents with relative permittivity between 10 and 40 . At this point the ions were treated as hard spheres and only pairwise interactions between them were considered, assumptions nowadays known as the "restricted primitive model" (RPM) [23]. The subsequent development of organic synthesis and the physical-chemical study of association of more complex molecules, concomitant with the development of new analysis methods, indicated that, when forming an ion pair, the interacting ions cannot be considered as being rigid and spherical [11]. Diamond proposed, in 1963, hydrophobic interaction, typical for large un-hydrated (hydrophobic) univalent ions, as a mechanism of ion-pair formation in aqueous solutions [4]. Such ions break the water structure producing hydrophobic cages around them, the driving force for the ion pairing being the water molecule preference to interact with itself by hydrogen bonding. The equilibrium is named water-structure enforced ion 
FARMACIA, 2019, Vol. 67, 4

pairing and the complexes formed accordingly water-structure enforced ion pairs. Ion pairing of the hydrophilic organic molecules of pharmaceutical interest, largely hydrated in water started to be studied using resonance light scattering (RLS) spectrometry. RLS, also known as resonance Rayleigh scattering, or enhanced Rayleigh scattering, is a simple, rapid and sensitive method for the study of aggregation of molecules. Starting with the 2000 s, a series of studies underlined the utility of the method in the assay of pharmaceuticals as ion pairs with organic dyes [5]. In this case, the ion pairs are formed mostly by experimentally conducted hydrophobic ion pairing. An increased ionic strength determines the chemical species involved in the ion pairing to become more hydrophobic because the solvent molecules in their hydration shell are attracted in competitive solvation equilibria of the inorganic ions [5]. A favourable effect on ion pairing of organic molecules in water solutions may be obtained by adding small quantities of methanol $\left(\mathrm{CH}_{3} \mathrm{OH}\right)$ or ethanol $\left(\mathrm{C}_{2} \mathrm{H}_{5} \mathrm{OH}\right)$ [5]. Solvent mixtures of water and alcohol have special importance because of their unique physical and chemical properties correlated with the concentration of alcohol [14]. At low molar fractions, $\mathrm{CH}_{3} \mathrm{OH}$ and $\mathrm{C}_{2} \mathrm{H}_{5} \mathrm{OH}$ have a strong waterstructuring effect $[13,15]$, so the hydrophobic interactions driving ion pairing can be enforced by engaging water and alcohol molecules in hydrogen bonds, thus dehydrating the substance of interest [5]. The aim of our research was to study the influence of water structuring effect of the alcohols $\left(\mathrm{CH}_{3} \mathrm{OH}\right.$, $\left.\mathrm{C}_{2} \mathrm{H}_{5} \mathrm{OH}\right)$ on ion pairing of organic molecules of pharmaceutical interest containing guanidine groups, namely streptomycin (STR) and arginine (AG). Congo red (CR), an azo dye, was used as counterion. The reason of using this dye in the study is the presence in its structure of two sulfonate groups. In biochemical researches, sulfonate moieties are given special attention, being considered in the molecular recognition schemes for purposes of drug development and for biological mimetic. In addition, in ion pairing, the advantage of using CR is that sulfonate groups are ionized in the aqueous media regardless of the surrounding medium $\mathrm{pH}[25]$.

$\mathrm{AG}$ is the most basic of all natural amino acids $(\mathrm{pKa}=12.5)$. In its free form or built into peptide, protein or receptor systems, can participate to electrostatic and directed hydrogen bond interactions with polar and anionic molecules by its planar, forklike guanidinium $\left(\mathrm{Gdm}^{+}\right)$functionality [25]. $\mathrm{Gdm}^{+}$ acts as hydrogen bond donor interacting strongly with water only in molecular plane, whereas its faces remain hydrophobic. Computational methods indicated like-charge ion pairing for $\mathrm{Gdm}^{+}$ions in water, characteristic with significant biochemical implications $[24,25]$. That property correlates with the geometry of the ion belonging to the class of planar Y-conjugated quasi-aromatic structures [27]. The cerebrospinal fluid analysis of Alzheimer's patients has elevated levels of AG though it remains uncertain whether this is a cause or a result of the disorder [16]. Recent evidence suggest that alcohol use may play an important role in the development of early-onset dementia [21]. STR is the first aminoglycoside antibiotic discovered, being isolated in 1943 from Streptomyces griseus. It was the first antibiotic used for the successfully treatment of tuberculosis. Currently is less used for this purpose due to the emergence of other broadspectrum antibiotics with fewer side effect. However, with the dramatically increasing rate of infections caused by multidrug-resistant bacteria, focus has returned to aminoglycoside antibiotics as one of the few remaining treatment options [1,28]. Chemically STR is made up of a disaccharide unit linked to the 4 - position of a guanidinylated streptamine. The hydroxyl groups contribute to its high hydrophilicity [1]. It has basic function due to the two guanidino groups and the secondary amino group. Reported $\mathrm{pK}$ values are $\mathrm{pK}_{1}=11.81 \pm 0.05, \mathrm{pK}_{2}=11.51 \pm 0.05$, $\mathrm{pK}_{3}=7.7 \pm 0.05$ [18], STR being mostly protonated in physiological conditions. In a previous work, the interaction between STR and CR in aqueous solutions was studied by means of UV-VIS absorption and RLS spectrometry. A RLS method for the assay of STR was proposed [6].

In the present work, the interaction of STR and $\mathrm{AG}$ with $\mathrm{CR}$ in $\mathrm{H}_{2} \mathrm{O} / \mathrm{CH}_{3} \mathrm{OH}$ and $\mathrm{H}_{2} \mathrm{O} / \mathrm{C}_{2} \mathrm{H}_{5} \mathrm{OH}$ binary solvent mixture was studied by means of absorption and RLS spectrometry, physico-chemical constants and molecular modelling. Analytical applications are also considered.

\section{Materials and Methods}

\section{Reagents}

Streptomycin sulphate (Sigma) as $3 \cdot 10^{-5} \mathrm{M}$, arginine (Janssen Chimica) as $1.5 \cdot 10^{-4} \mathrm{M}$ and Congo red (Scharlau) as $2 \cdot 10^{-4} \mathrm{M}$ aqueous solutions were used. Britton-Robinson (BR) buffer solutions were prepared using an equimolar mixture of $\mathrm{H}_{3} \mathrm{PO}_{4}$, $\mathrm{CH}_{3} \mathrm{COOH}$ and $\mathrm{H}_{3} \mathrm{BO}_{3}\left(4 \cdot 10^{-2} \mathrm{M}\right)$ in water, the $\mathrm{pH}$ of the buffer being potentiometrically adjusted at values 5.5, 6.5 and 7.5 using $\mathrm{NaOH} 10^{-1} \mathrm{M}$ solution. $\mathrm{CH}_{3} \mathrm{OH}(99.8 \%, \rho=0.792 \mathrm{~g} / \mathrm{mL})$ and $\mathrm{C}_{2} \mathrm{H}_{5} \mathrm{OH}(96 \%$, $\rho=0.810 \mathrm{~g} / \mathrm{mL}$ ) analytical grade solvents from Chemical Company and double-distilled water were used throughout.

General procedure

Into a $10 \mathrm{~mL}$ volumetric flask $1 \mathrm{~mL}$ of $\mathrm{CR}$, appropriate amounts of STR or AG and $1 \mathrm{~mL}$ of BR buffer solution were mixed. The amount needed of water to $9 \mathrm{~mL}$ and $1 \mathrm{~mL} \mathrm{CH} \mathrm{CH}_{3} \mathrm{OH}, \mathrm{C}_{2} \mathrm{H}_{5} \mathrm{OH}$ respectively were added and thoroughly mixed. The reagent blank was prepared using the same procedure, without STR or AG. 
Apparatus

Absorption spectra were recorded using a UV-VIS Cary 100 Bio (Varian Inc.) spectrophotometer.

RLS spectra were recorded on a Perkin Elmer LS50B spectrofluorimeter using a $1 \mathrm{~cm}$ path length quartz cell and $1 \%$ emission attenuation filter. Synchronous scanning at the same excitation and emission wavelength $\left(\lambda_{\text {excitation }}=\lambda_{\text {emision }}\right)$, after 5 min, for $\mathrm{H}_{2} \mathrm{O} / \mathrm{C}_{2} \mathrm{H}_{5} \mathrm{OH}$ and 15 for $\mathrm{H}_{2} \mathrm{O} / \mathrm{CH}_{3} \mathrm{OH}$, at room temperature, was performed. The RLS intensity (I) for the ion pair and the reagent blank $\left(I_{0}\right)$ at the maximum RLS wavelength were measured $\left(\Delta I=I-I_{o}\right)$.

The $\mathrm{pH}$ measurements were made using a Metrohm 716 DMS Titrino $\mathrm{pH}-$ meter.

Conductivity measurements were performed at a Corning Conductivity Meter 441, and dielectric constant was determined on a Radelkis Dielectric Constant Meter.

Molecular modelling

In order to obtain the most stable conformations (with minimum internal energy), conformational studies were conducted by using the Conformational Search program from HyperChem Professional package 7.5
[29]. The following steps were run over: (1) for the structures in a random conformation, but with defined bond length and angles, all flexible bonds and rings were set up and used in the conformational analysis; (2) to minimize the energy, in order to obtain a more stable conformation of the molecules AMBER (Assisted Model Building and Energy Refinement) force field with distance dependent dielectric constant was used, electrostatic and van der Waals 1 - 4 scale factors were set to 0.5 and cut-offs set to none; (3) the minimizing of the conformation energy was conducted until the total root-mean-square (RMS). The geometry optimization parameters were: Polak-Ribiere (conjugate gradient) algorithm, RMS gradient of $0.1 \mathrm{kcal} / \mathrm{mol} * \AA$, in vacuum, without periodic boundary conditions [19].

\section{Results and Discussion}

\section{Molecular modelling}

Ion pairing of $\mathrm{AG}$ and $\mathrm{CR}$ can take place in two different ways: a) electrostatic interaction between $\mathrm{Gdm}^{+}$and $-\mathrm{SO}_{3}{ }^{-}$or $\mathrm{b}$ ) cation $\cdots \pi$ interaction between $\mathrm{Gdm}^{+}$and aromatic nucleus of CR (Figure 1).

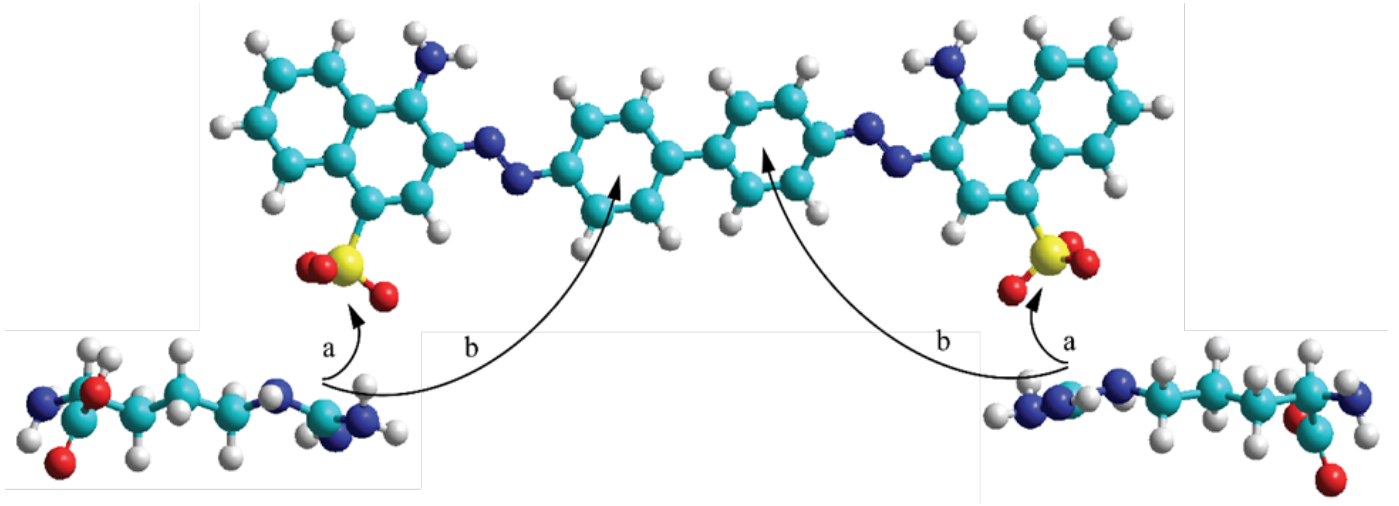

Figure 1.

The possibilities of interaction between AG and CR

The assumption is based on the literature data [2] correlated with the geometry of the molecules. In both cases a 1:2 CR:AG ion pair is obtained as presented in the reaction:

$$
\mathrm{CR}^{2-}+2 \mathrm{AG}^{+}=\mathrm{CR}^{2-} \cdot 2 \mathrm{AG}^{+}
$$

In the $\mathrm{pH}$ range $5.5-7.5$, according to the charge densities reported [6], STR is protonated at the guanidinum groups being $\mathrm{STR}^{2+}$. With $\mathrm{CR}^{2-}$ can form a 1:1 ion pair:

$$
\mathrm{CR}^{2-}+\mathrm{STR}^{2+}=\mathrm{CR}^{2-} \cdot \mathrm{STR}^{2+}
$$

The interaction of STR with CR, due to the hydroxyl groups is more than electrostatic, H-bonds being formed.

Dielectric properties of $\mathrm{H}_{2} \mathrm{O} / \mathrm{CH}_{3} \mathrm{OH}$ and $\mathrm{H}_{2} \mathrm{O} / \mathrm{C}_{2} \mathrm{H}_{5} \mathrm{OH}$ mixtures

For $\mathrm{CH}_{3} \mathrm{OH}$ and $\mathrm{C}_{2} \mathrm{H}_{5} \mathrm{OH}$, at low molar fractions in water, it was described a phenomenon of hydrophobic hydration, interpreted structurally in terms of the "iceberg" picture [8, 17]. In the $\mathrm{CH}_{3} \mathrm{OH}$ case, studies indicated that, at molar fractions of 0.048 , the alcohol molecules are substituting a part of water molecules in the hydrogen - bonding network of water [22]. This property could have a favourable effect on ion pairing of organic hydrophilic molecules.

For the $\mathrm{H}_{2} \mathrm{O} / \mathrm{CH}_{3} \mathrm{OH}$ and $\mathrm{H}_{2} \mathrm{O} / \mathrm{C}_{2} \mathrm{H}_{5} \mathrm{OH}$ mixtures used in the present study, dielectric constants were determined. In Figure 2 is presented the variation of the determined parameter as function of the molar fraction of $\mathrm{CH}_{3} \mathrm{OH}$.

For $\mathrm{CH}_{3} \mathrm{OH}$, a linear correlation of dielectric constant with the concentration of alcohol exist for molar fractions between 0.1 and $0.9(\mathrm{r}=0.9998)$, and respectively for $\mathrm{C}_{2} \mathrm{H}_{5} \mathrm{OH}$ for molar fractions between 0.07 and $0.9(r=0.9999)$. The results confirm that, for the studied water/alcohol mixtures with molar fraction of methanol lower than 0.1 and for ethanol 
FARMACIA, 2019, Vol. 67, 4

lower than 0.07 , respectively, characteristic structural properties exist. The following determinations were performed on solutions prepared in a water/alcohol mixture with a molar fraction of 0.05 and 0.03 , $\mathrm{CH}_{3} \mathrm{OH}$ respectively, of $\mathrm{C}_{2} \mathrm{H}_{5} \mathrm{OH}$, obtained by mixing $9 \mathrm{~mL}$ of water and $1 \mathrm{~mL}$ of alcohol.

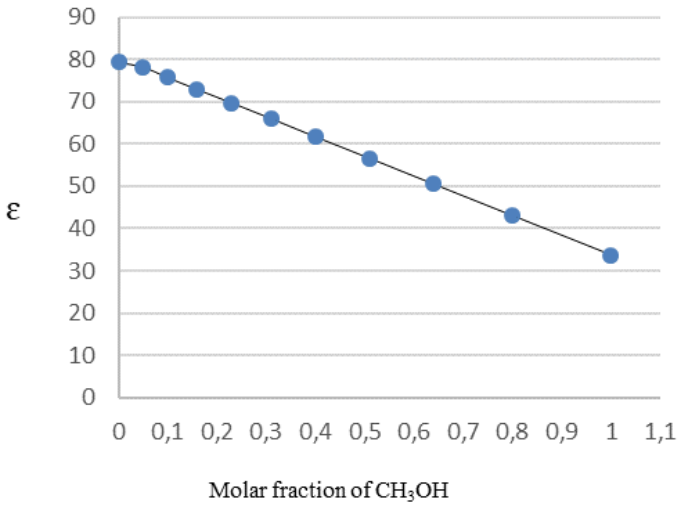

Figure 2.

Variation of dielectric constant of $\mathrm{H}_{2} \mathrm{O} / \mathrm{CH}_{3} \mathrm{OH}$ mixture

\section{Conductometric determinations}

For asymmetric electrolytes (e.g., 2:1 electrolytes), ion pairing reduces the number of charge carriers in solution and the associated ions possess a lower mobility due to the increased hydrodynamic volume. Thus, ion pairing leads to a marked reduction of the conductance compared to the limiting case of a completely dissociated electrolyte solution. This fact renders conductance measurements an excellent tool to study the association behaviour of salt solutions [9]. Conductivity measurements were performed for solutions of $2 \cdot 10^{-5} \mathrm{M} \mathrm{CR}$, STR-CR $\left(6.2 \cdot 10^{-6} \mathrm{M} \mathrm{STR}\right)$ and AG-CR (1.5 $\left.\cdot 10^{-5} \mathrm{M} \mathrm{AG}\right)$ in $\mathrm{H}_{2} \mathrm{O}, \mathrm{H}_{2} \mathrm{O} / \mathrm{CH}_{3} \mathrm{OH}$ $(9 / 1 \mathrm{v} / \mathrm{v})$ and $\mathrm{H}_{2} \mathrm{O} / \mathrm{C}_{2} \mathrm{H}_{5} \mathrm{OH}(9 / 1 \mathrm{v} / \mathrm{v})$ and $\mathrm{BR}$ buffer with $\mathrm{pH} 5.5,6.5$ and 7.5. During the determinations the temperature increased from $298.15 \mathrm{~K}$ to 230.15 $\mathrm{K}$ and the time interval during which they were performed was 2 hours. The results obtained are presented in Table I.

The results indicate electrostatic interactions in solutions of STR-CR in the entire $\mathrm{pH}$ range used, for $\mathrm{H}_{2} \mathrm{O}$ / $\mathrm{CH}_{3} \mathrm{OH}$ and $\mathrm{H}_{2} \mathrm{O} / \mathrm{C}_{2} \mathrm{H}_{5} \mathrm{OH}$ solutions and for AG-CR in $\mathrm{H}_{2} \mathrm{O} / \mathrm{CH}_{3} \mathrm{OH}$ solution.

For AG-CR, in $\mathrm{H}_{2} \mathrm{O} / \mathrm{C}_{2} \mathrm{H}_{5} \mathrm{OH}$ solutions these interactions appear at $\mathrm{pH} 5.5$ and 6.5. At $\mathrm{pH} 7.5$ an increase of the conductivity is observed for the solution of AG-CR in $\mathrm{H}_{2} \mathrm{O} / \mathrm{C}_{2} \mathrm{H}_{5} \mathrm{OH}$. This may be due to the increase of the concentration of free $\mathrm{Gdm}^{+}$ions by detachment from $\mathrm{Gdm}^{+}: \mathrm{Gdm}^{+}$like ion pairs.

Another interesting observation is that for the solutions prepared in $\mathrm{H}_{2} \mathrm{O} / \mathrm{CH}_{3} \mathrm{OH}$ and $\mathrm{H}_{2} \mathrm{O} / \mathrm{C}_{2} \mathrm{H}_{5} \mathrm{OH}$, the measured conductivity remains constant as the temperature increase, in the entire $\mathrm{pH}$ range studied, unlike solutions prepared in $\mathrm{H}_{2} \mathrm{O}$ where an increase of the measured conductivity appears. The observation is an evidence for the stabilization effect determined by the presence of the alcohols in the reaction media.

Table I

Conductivity values measured for solutions of CR, STR-CR and AG-CR

\begin{tabular}{|l|c|c|c|}
\hline \multirow{4}{*}{ Solvent } & \multicolumn{3}{|c|}{ Conductivity $(\boldsymbol{\mu S} / \mathbf{c m})$} \\
\cline { 2 - 4 } & $\mathbf{R C}$ & STR-CR & AG-CR \\
\hline \multicolumn{4}{|c|}{$\mathrm{pH}=5.5$} \\
\hline $\mathrm{H}_{2} \mathrm{O}$ & $429 \rightarrow 459$ & $450 \rightarrow 473$ & $428 \rightarrow 458$ \\
\hline $\mathrm{H}_{2} \mathrm{O} / \mathrm{CH}_{3} \mathrm{OH}$ & 393 & 393 & 380 \\
\hline $\mathrm{H}_{2} \mathrm{O} / \mathrm{C}_{2} \mathrm{H}_{5} \mathrm{OH}$ & 373 & 373 & 372 \\
\hline \multicolumn{4}{|c|}{$\mathrm{pH}=6.5$} \\
\hline $\mathrm{H}_{2} \mathrm{O}$ & $536 \rightarrow 542$ & $489 \rightarrow 519$ & $519 \rightarrow 527$ \\
\hline $\mathrm{H}_{2} \mathrm{O} / \mathrm{CH}_{3} \mathrm{OH}$ & 443 & 432 & 440 \\
\hline $\mathrm{H}_{2} \mathrm{O} / \mathrm{C}_{2} \mathrm{H}_{5} \mathrm{OH}$ & 418 & 412 & 413 \\
\hline \multicolumn{4}{|c|}{$\mathrm{pH}=7.5$} \\
\hline $\mathrm{H}_{2} \mathrm{O}$ & $627 \rightarrow 636$ & $615 \rightarrow 630$ & $606 \rightarrow 628$ \\
\hline $\mathrm{H}_{2} \mathrm{O} / \mathrm{CH}_{3} \mathrm{OH}$ & 532 & 519 & 521 \\
\hline $\mathrm{H}_{2} \mathrm{O} / \mathrm{C}_{2} \mathrm{H}_{5} \mathrm{OH}$ & 489 & 490 & 497 \\
\hline
\end{tabular}

\section{Spectral characteristics}

Ion pair formation is revealed spectrophotometrically by a shift of the absorption peak of the chromophore. Spectral changes are determined by the additional interactions (aromatic staking, charge transfer, hydrogen bonds) that occur with the electrostatic ones when an ion pair is formed. When the interaction between ions is strictly electrostatic in the absorption spectrum, no changes occur [5].

$U V$-Vis absorption spectra

Changes in the UV-Vis absorption spectra correlated with the formation of STR - CR ion pair are a hypochromic effect and a hypsochromic shift of the two maxima of the dye. In Table II, changes are summarized and presented comparative with the changes reported for the STR-CR ion pairing in water.

Spectral changes in the absorption spectra indicating STR-CR ion pairing

\begin{tabular}{lcccccc}
\hline \multirow{2}{*}{ Solvent } & \multicolumn{2}{c}{ CR } & \multicolumn{2}{c}{ STR - CR ion pair } & Blue shift & $\begin{array}{c}\text { Hypsochromic effect } \\
\end{array}$ \\
\cline { 2 - 5 } & $\lambda(\mathrm{nm})$ & Absorbance & $\lambda(\mathrm{nm})$ & Absorbance & $\Delta \lambda$ & $(\Delta \mathrm{A})$ \\
\hline $\mathrm{H}_{2} \mathrm{O} / \mathrm{CH}_{3} \mathrm{OH}$ & 499 & 0.407 & 493 & 0.318 & $6 \mathrm{~nm}$ & -0.089 \\
$(9 / 1 \mathrm{v} / \mathrm{v})$ & 341 & 0.322 & 338 & 0.311 & $3 \mathrm{~nm}$ & -0.011 \\
\hline $\mathrm{H}_{2} \mathrm{O} / \mathrm{C}_{2} \mathrm{H}_{5} \mathrm{OH}$ & 500 & 0.436 & 497 & 0.363 & $3 \mathrm{~nm}$ & -0.073 \\
$(9 / 1 \mathrm{v} / \mathrm{v})$ & 341 & 0.305 & 380 & 0.277 & $1 \mathrm{~nm}$ & -0.028 \\
\hline $\mathrm{H}_{2} \mathrm{O}[6]$ & 497 & 0.430 & 488 & 0.310 & $9 \mathrm{~nm}$ & - \\
& 343 & 0.308 & 338 & 0.290 & $5 \mathrm{~nm}$ & - \\
\hline
\end{tabular}


Blue shift in the absorption spectra is dependent on the medium polarity. Compared with water, $9 / 1 \mathrm{v} / \mathrm{v}$ $\mathrm{H}_{2} \mathrm{O} / \mathrm{CH}_{3} \mathrm{OH}$ and $\mathrm{H}_{2} \mathrm{O} / \mathrm{C}_{2} \mathrm{H}_{5} \mathrm{OH}$ mixtures have lower relative permittivity: 78.20 and 78.56 respectively. Accordingly, blue shifts of the absorption maxima are lower. The intense hypochromic effect indicate STR - CR ion pairing by hydrophobic interaction, thus confirming the favourable effect assumed for the $\mathrm{CH}_{3} \mathrm{OH}$ and $\mathrm{C}_{2} \mathrm{H}_{5} \mathrm{OH}$, at low molar fractions in water.

For the solutions containing AG-CR ion pairs, no changes in the absorption spectra were observed.

Resonance light scattering spectra

In the RLS spectra, for $\mathrm{H}_{2} \mathrm{O} / \mathrm{CH}_{3} \mathrm{OH}$ and $\mathrm{H}_{2} \mathrm{O} / \mathrm{C}_{2} \mathrm{H}_{5} \mathrm{OH}$ solutions of STR and CR alone very weak RLS signals were obtained. When the two agents react with each other, a significant enhancement of the RLS intensity appeared in the range $300-450 \mathrm{~nm}$, with the maximum scattering peak located at $380 \mathrm{~nm}$ (Figure 3 ).

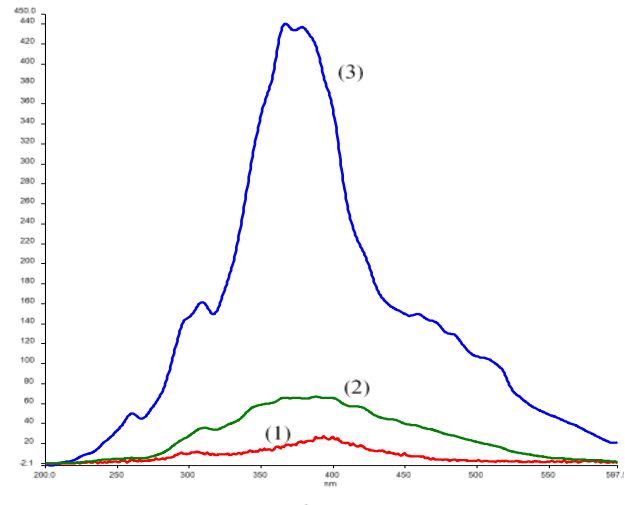

Figure 3.

The RLS spectra of (1) CR (14.10 $\mu \mathrm{g} / \mathrm{mL})$, (2) STR $(9.81 \mu \mathrm{g} / \mathrm{mL})$ and STR-CR ion-pair $(9.81 \mu \mathrm{g} / \mathrm{mL})$ in $\mathrm{H}_{2} \mathrm{O} / \mathrm{C}_{2} \mathrm{H}_{5} \mathrm{OH} 9 / 1(\mathrm{v} / \mathrm{v})$ binary solvent mixture
In the $\mathrm{AG}$ case, in the RLS spectra, changes were observed in $\mathrm{H}_{2} \mathrm{O} / \mathrm{C}_{2} \mathrm{H}_{5} \mathrm{OH}$ solutions when BR buffer with $\mathrm{pH} 7.5$ was used. For the solution containing $\mathrm{AG}$ and $\mathrm{CR}$, a decrease of the intensity of the maximum at $396 \mathrm{~nm}$ with the increase of the concentration of AG was observed. This can be due to the detachment from $\mathrm{Gdm}^{+} \cdot \mathrm{Gdm}^{+}$like ion pairs, result that is in accordance with the observations on the conductivity measurements.

Analytical applications of the STR-CR ion pairing For STR-CR ion pair formed in $\mathrm{H}_{2} \mathrm{O} / \mathrm{CH}_{3} \mathrm{OH}$ and $\mathrm{H}_{2} \mathrm{O} / \mathrm{C}_{2} \mathrm{H}_{5} \mathrm{OH}$ 9/1 (v/v) optimum experimental conditions (buffer $\mathrm{pH}$, counterion concentration, ion pair stability, reagents addition order) were determined for a quantitative ion pairing that can be used for the determination of STR.

Thus, spectral changes indicated that optimum $\mathrm{pH}$ value of the buffer is 5.5. $1 \mathrm{~mL}$ of $\mathrm{pH}=5.5 \mathrm{BR}$ buffer was used. CR optimum concentration was established to be $2 \cdot 10^{-5} \mathrm{M}$.

The reaction time is 5 minutes in $\mathrm{H}_{2} \mathrm{O} / \mathrm{CH}_{3} \mathrm{OH}(9 / 1 \mathrm{v} / \mathrm{v})$ and 15 minutes for $\mathrm{H}_{2} \mathrm{O} / \mathrm{C}_{2} \mathrm{H}_{5} \mathrm{OH}(9 / 1 \mathrm{v} / \mathrm{v})$ reaction media. The RLS intensity remains constant for at least 2 hours indicating a good stability of STR-CR ion pair. The optimum sequence of reagents addition: (1) CR solution, (2) STR solution, (3) BR buffer solution, (4) water and (5) alcohol.

In the established experimental conditions for $\mathrm{H}_{2} \mathrm{O} / \mathrm{CH}_{3} \mathrm{OH}$ solvent mixture, we obtained a linear correlation between the decrease of the absorbance and concentration of STR at the wavelength $493 \mathrm{~nm}$. When $\mathrm{H}_{2} \mathrm{O} / \mathrm{C}_{2} \mathrm{H}_{5} \mathrm{OH}$ solvent mixture was used, a linear correlation between the intensity of the scattered light and concentration of STR at the wavelength $380 \mathrm{~nm}$ was observed. In Table III, a comparison of the sensitivity of the proposed methods with the previously published is presented.

Table III

The comparative presentation of the performance parameters of the STR assay methods based on ion pairing

\begin{tabular}{lcccc}
\hline \multicolumn{1}{c}{ Solvent } & Linearity range $(\mu \mathrm{g} / \mathrm{mL})$ & LOQ $(\mu \mathrm{g} / \mathrm{mL})$ & LOD $(\mu \mathrm{g} / \mathrm{mL})$ & Reference \\
\hline $\mathrm{H}_{2} \mathrm{O} / \mathrm{CH}_{3} \mathrm{OH}$ & $2.29-6.87$ & $0.09^{*}$ & $0.32^{*}$ & Present work \\
\hline $\mathrm{H}_{2} \mathrm{O} / \mathrm{C}_{2} \mathrm{H}_{5} \mathrm{OH}$ & $9.73-16.22$ & $9.73^{* *}$ & $2.05^{* *}$ & Present work \\
\hline $\mathrm{H}_{2} \mathrm{O}$ & $6.49-9.47$ & 6.49 & 6 & {$[6]$} \\
\hline
\end{tabular}
with CR

*based on the slope of calibration curve and standard deviation of the blank, **according to the procedure described in the reference 6

Accuracy studies for the RLS method were performed, using standard samples at three levels of STR concentration, every sample being analysed in triplicate, using the General procedure previously described. The percent recovery ranged between $99.2 \%$ and $101.4 \%$ for the absorption based method and 99.2 $101.9 \%$ for the RLS method, providing a good accuracy.

Although widely used in the treatment of tuberculosis [20], and formalized over time in various pharmacopoeias [26], at the time of making the determinations, on the local pharmaceutical market no pharmaceutical formulations were available containing STR. Consequently, the methods proposed could not be applied to the assay of STR in pharmaceuticals, but they can be considered as alternatives to the analysis of other types of probes.

\section{Conclusions}

The influence of water structuring effect of $\mathrm{CH}_{3} \mathrm{OH}$ and $\mathrm{C}_{2} \mathrm{H}_{5} \mathrm{OH}$ on the ion pairing of STR respectively $\mathrm{AG}$, with $\mathrm{CR}$ was studied. The optimum solvent 
mixture - 9/1 v/v water/alcohol, corresponding to 0.05 molar fraction of $\mathrm{CH}_{3} \mathrm{OH}$ and 0.03 molar fraction of $\mathrm{C}_{2} \mathrm{H}_{5} \mathrm{OH}$ - was selected based on dielectric constant determinations. Conductometric measurements indicated the existence of the electrostatic interactions in the case of the STR - CR ion pair in the $\mathrm{pH}$ range 5.5 - 7.5 in both reaction media. The same observations were made for the interaction of $A G$ with $C R$, with the exception of $\mathrm{H}_{2} \mathrm{O} / \mathrm{C}_{2} \mathrm{H}_{5} \mathrm{OH}$ mixture when $\mathrm{BR}$ with $\mathrm{pH} 7.5$ was used. In this case, the conductivity value of the solution increased, change that can be attributed to the dissociation of the $\mathrm{Gdm}^{+}: \mathrm{Gdm}^{+}$like ion pair, and suggested also by the RLS spectra.

Spectral characteristics of the STR-CR ion pair, in both solvent mixtures, using BR with $\mathrm{pH} 5.5$ were considered for analytical applications. Linearity range obtained for the maximum in the RLS spectra, 9.73 $16.22 \mu \mathrm{g} / \mathrm{mL}$, is larger than that obtained in the previously RLS published method $(6.49-9.74 \mu \mathrm{g} / \mathrm{mL})$ for the assay of STR.

\section{Acknowledgement}

This paper was financially supported by "Carol Davila" University of Medicine and Pharmacy through Contract no. CNFIS-FDI-2019-0534 (MEDEX-II) funded by the Ministry of National Education of Romania, from the Institutional Development Fund for Public Universities - FDI 2019.

\section{References}

1. Becker B, Cooper MA, Aminoglycoside antibiotics in the $21^{\text {st }}$ Century. ACS Chem Biol., 2013; 8: 105-115.

2. Campo-Cacharrón A, Cabaleiro-Lago EM, CarrazanaGarcía JA, Rodríguez-Otero J, Interaction of aromatic units of amino acids with guanidinium cation: the interplay of $\pi \cdots \pi, \mathrm{X}-\mathrm{H} \cdots \pi$, and $\mathrm{M}^{+} \cdots \pi$ contacts. J Comput Chem., 2014; 35: 1290-1301.

3. Constantinescu IC, Florea M, Neagu AF, Development of a spectrophotometric method for determination of fluoxetine hydrochloride in bulk and pharmaceutical dosage forms. Farmacia, 2015; 63(6): 816-820.

4. Diamond RM, The aqueous solution behavior of large univalent ions. A new type of ion-pairing. $J$ Physic Chem., 1963; 67: 2513-2517.

5. Florea M, Ilie M, Ion-pair spectrophotometry in pharmaceutical and biomedical analysis: Challenges and perspectives. In Spectroscopic analyses Developments and applications. InTech, Croatia, 2017; 173-192

6. Florea M, Monciu CM, Ilie M, Resonance Rayleigh scattering spectra study of streptomycin - Congo red ionic association in view of analytical application. Farmacia, 2014; 62(2): 318-328.

7. Florea M, Monciu CM, Ilie M, Determination of nimesulide by ion pair high-performance liquid chromatography using tetrabutylammonium as the counterion. Anal Lett., 2015; 48: 328-339.

8. Frank HS, Evans MW, Free volume and entropy in condensed system III. Entropy in binary liquid mixtures - partial molal entropy in dilute solutions - structure and thermodynamics in aqueous electrolytes. J Chem Phys., 1945; 13: 507-532.

9. Hunger J, Neueder R, Buchner R, Apelblat A, A conductance study of guanidinum chloride, thiocyanate, sulfate and carebonate in dilute aqueous solutions: ion-association and carbonate hydrolysis effect. $J$ Phys Chem B, 2013; 117(2): 615-622.

10. IUPAC. Compendium of Chemical Terminology, $2^{\text {nd }}$ Ed. (the "Gold Book"). Complied by McNaught AD, Wilkinson A. Blackwell Scientific Publications, Oxford (1997), http://goldbook.iupac.org.

11. Ishchenko AA, Shapovalov SA, Heterogeneous association of the ions of dyes in solutions. $J$ Appl Spectrosc., 2004; 71(5): 605-629.

12. Jonkman JHG, Hunt CA, Ion pair absorption of ionized drugs - fact or fiction?. Pharmaceutisch Weekblad Scientific Edition, 1983; 5: 41-48.

13. Laaksonen A, Kusalik PG, Svishchev IM, Threedimensional structure in water-methanol mixtures, J Phys Chem A, 1997; 101: 5910-5918.

14. Wei-Na L, Jun-Hong W, Effective permittivity of alcohol + water mixtures as influenced by concentration. J Chem Pharm Res., 2014; 6(7): 1432-1434.

15. Mejía SM, Mills MJL, Shaik MS, Mondragon F, Popelier LA, The dynamic behaviour of a liquid ethanol - water mixture: a perspective from quantum chemical topology. Phys Chem Chem Phys., 2011; 13: 7821-7833.

16. Mohlake P, Whiteley CG, Arginine metabolising enzymes as therapeutic tools for Alzheimer's disease: peptidyl arginine deiminase catalyses fibrillogenesis of $\beta$-amyloid peptides. Mol Neurobiol., 2010; 41: 149-158.

17. Noskov SY, Lamoureux G, Roux B, Molecular dinamics study of hydration in ethanol-water mixtures using a polarizable force field. J Phys Chem B, 2005; 109: 6705-6713.

18. Nys PS, Savitskaya EM, Kolygina TS, Determination of ionization constants of streptomycin by the indicator method. Pharm Chem J., 1971; 5(9): 576-579.

19. Purdel CN, Florea M, Guțu CM, Dănciulescu Miulescu R, Ilie M, Aramă CC, Molecular modeling and experimental investigations of the interaction between fluoxetine and beta-cyclodextrin in aqueous solution. Romanian J Biophys., 2014; 24(2): 75-87.

20. Rais C, Taerel AE, Ștefănescu E, Brumărel M, Safta V, Adajni S, Priscu V, Soroceanu V, Epidemiological aspects of tuberculosis in adults in Romania versus Republic of Moldova. Farmacia, 2016; 64(4): 643-650.

21. Rehm J, Hasan OSM, Black SE, Shield KD, Schwarzinger M, Alcohol use and dementia: a systematic scoping review. Alzheimers Res Ther., 2019; 11: 1-11.

22. Warkisaka A, Komatsu S, Usui Y, Solute-solvent and solvent-solvent interactions evaluated through clusters isolated from solutions: Preferential solvation in water-alcohol mixtures. J Mol Liquids, 2001; 90: 175-184.

23. Yizhak M, Glenn H, Ion Pairing. Chem Rev., 2006, 106: 4585-4621.

24. Shih O, England AH, Dallinger GC, Smith JW, Duffey KC, Cohen RC, Prendergast D, Saykally RJ, Cationcation contact pairing in water: Guanidinium. $J$ Chem Phys., 2013; 139: 1-7. 
FARMACIA, 2019, Vol. 67, 4

25. Shung KA, Lindner W, Noncovalent binding between guanidinium and anionic groups: Focus on biologicaland synthetic-based arginine/guanidinum interctions with phosph[on]ate and sulf[on]ate residues. Chem Rev., 2005; 105: 67-113.

26. Stancu E, Carata A, Taerel AE, Soroceanu V, The study of pharmacopoeias used in the Romanian area in XVIII-XX ${ }^{\text {th }}$ centuries: Evolution of proportions for drug substances and pharmaceutical preparations. Farmacia, 2014; 62(5): 1037-1048.
27. Vazdar M, Heyda J, Mason PE, Tesei G, Allolio C, Lund M, Jungwirth, Arginine "Magic": Guanidinium Like-charge ion pairing from aqueous salts to cell penetrating peptides. Acc Chem Res., 2018, 51(6): 1455-1646.

28. Taerel AE, Soroceanu V, Rais C, Trends in the evolution of the annual classified list of medicines between 1989 - 2012. Farmacia, 2013; 61(5): 948-956.

29. *** HyperChem 7.5 Release for Windows, HyperCube, Inc., Gainsville, Florida, USA. 